\title{
Caracterização Morfocultural e Molecular de Isolados de Colletotrichum gloeosporioides Patogênicos ao Mamoeiro
}

\author{
Eiko M. Andrade ${ }^{1}$, Carlos H. Uesugi ${ }^{1}$, Bernardo Ueno ${ }^{2}$ \& Marisa A.S.V. Ferreira ${ }^{1}$ \\ ${ }^{1}$ Departamento de Fitopatologia, Universidade de Brasília, CEP 70910-900, Brasília, DF,

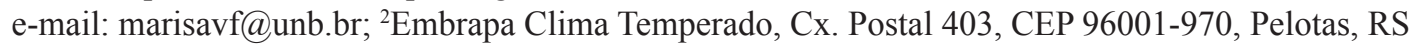

Autor para correspondência: Marisa A.S.V. Ferreira

ANDRADE, E.M., UESUGI, C.H., UENO, B. \& FERREIRA, M.A.S.V. Caracterização morfocultural e molecular de isolados de Colletotrichum gloeosporioides patogênicos ao mamoeiro. Fitopatologia Brasileira 32:021-031. 2007.

\begin{abstract}
RESUMO
Vinte e nove culturas monospóricas de Colletotrichum, isoladas de frutos e pecíolos de mamoeiro (Carica papaya), foram caracterizadas quanto à morfologia dos conídios e apressórios, coloração e crescimento das colônias, sensibilidade ao benomyl, presença de setas e do teleomorfo, PCR com primers taxon-específicos e análise de PCR-RFLP da região ITS. Os 29 isolados foram identificados como C. gloeosporioides com base na morfologia dos conídios e apressórios, tendo a maioria dos isolados conídios cilíndricos e/ou obclavados e apressórios lobados ou fracamente lobados, em contraste com $C$. acutatum, isolado de morango (Fragaria x ananassa), que apresentou conídios fusiformes e apressórios circulares e lisos. Presença de setas e do teleomorfo, cor de colônia, sensibilidade ao benomyl e velocidade de crescimento variaram conforme o isolado e sofreram influência do meio de cultura usado. Todos os isolados de mamão e quatro de outras hospedeiras, manga (Mangifera indica), morango e maçã (Malus domestica), foram patogênicos a frutos de mamão cv. Sunrise Solo, mas com variabilidade em agressividade. PCR com o primer específico para C. gloeosporioides, CgInt, confirmou a identidade de apenas quatro isolados de mamão e dois isolados apresentaram reação positiva com o primer CaInt2, específico para $C$. acutatum. A maioria dos isolados de mamão (23) não reagiu com nenhum dos primers. Por outro lado, a análise de restrição da região ITS do rDNA, com RsaI, gerou perfis distintos entre C. gloeosporioides e C. acutatum e mostrou uniformidade entre os isolados de mamão.
\end{abstract}

Palavras-chave adicionais: antracnose, mancha-chocolate, Carica papaya, DNA ribossomal, Colletotrichum acutatum.

\begin{abstract}
Morphocultural and molecular characterization of Colletotrichum gloeosporioides isolates pathogenic to papaya

Twenty-nine monoconidial cultures of Colletotrichum isolated from papaya (Carica papaya) petioles and fruits were characterized by conidial and appressoria morphology, colony color, growth rate, sensitivity to benomyl, presence of setae, presence of the teleomorph, PCR with taxon-specific primers and analysis of PCR-RFLP of the ITS region. The 29 isolates from papaya were identified as C. gloeosporioides, based mainly on conidial and appressoria morphology, with most isolates producing cylindrical and/or obclavate conidia and entirely or weakly lobed appressoria, in contrast with the strawberry (Fragaria x ananassa) isolate of C. acutatum, which produced fusiform conidia and circular appressoria with entire edges. Presence of setae, teleomorphic stage, colony color, sensitivity to benomyl and growth rate were variable among isolates and influenced by the culture medium. All papaya isolates and four isolates (C. gloeosporioides and $C$. acutatum) from other hosts, mango (Mangifera indica), strawberry and apple (Malus domestica), were pathogenic to papaya fruits cv. Sunrise Solo, producing similar symptoms, but with variability in aggressiveness. PCR with $C$. gloeosporioidesspecific primer, CgInt, confirmed the identity of four papaya isolates. Two other isolates reacted with C. acutatum-specific primer, CaInt2. The majority of papaya isolates (23), however, did not react with any of the primers tested. In contrast, RFLP analysis of the amplified ITS region with $R s a \mathrm{I}$, generated distinct patterns that could differentiate between the two species, C. gloeosporioides and C. acutatum, and showed uniformity among papaya isolates.
\end{abstract}

Additional keywords: anthracnose, chocolate spot, Carica papaya, ribosomal DNA, Colletotrichum acutatum.

\section{INTRODUÇÃO}

Colletotrichum gloeosporioides (Penz.) Penz. \& Sacc. causa a antracnose, podridão-peduncular e a manchachocolate em frutos do mamoeiro (Alvarez \& Nishijima, 1987; Oliveira et al., 2000; Ueno et al., 2001). A antracnose

\footnotetext{
*Parte da Dissertação de Mestrado do primeiro autor. Universidade de Brasília. Brasília, DF. 2003.
}

é uma das doenças mais sérias do mamoeiro e não só ataca os frutos como também causa amarelecimento e danos aos pecíolos das folhas (Gayet et al., 1995). Ainda que os frutos colhidos não apresentem sintomas da doença, ela se manifesta na fase de embalagem, transporte, amadurecimento e comercialização (Oliveira et al., 2000). A mancha-chocolate caracteriza-se por pequenas manchas superficiais de coloração marrom avermelhada. Embora descritas como doenças distintas, tanto a antracnose quanto a mancha-chocolate são atribuídas a $C$. gloeosporioides 
(Alvarez \& Nishijima, 1987; Dickman, 1994).

Espécies de Colletotrichum são tradicionalmente diferenciadas com base em caracteres morfológicos e culturais. Características como morfologia de conídios, presença de setas e do teleomorfo, coloração de colônia, produção de pigmentos e taxa de crescimento têm sido usadas para diferenciar espécies morfologicamente próximas, como $C$. gloeosporioides e C. acutatum J.H. Simmonds (Sutton, 1992; Freeman et al., 1998). As dificuldades encontradas na identificação das espécies de Colletotrichum estão relacionadas à grande diversidade fenotípica, influência de fatores ambientais na estabilidade dos caracteres morfológicos e culturais, existência de formas intermediárias e falta de padronização de condições culturais empregadas nos diferentes estudos (Sutton, 1992; Freeman et al., 1998; Lopez, 2001).

A diferenciação entre espécies com base no círculo de hospedeiros ou hospedeiro de origem também não é um critério confiável para espécies como $C$. gloeosporioides e C. acutatum que infectam diferentes hospedeiras (Freeman et al., 1998; Peres et al. 2005). É freqüente a ocorrência de mais de uma espécie de Colletotrichum associada a uma mesma hospedeira e uma mesma espécie pode atacar múltiplas hospedeiras (Freeman et al.,1998). Colletotrichum gloeosporioides e C. acutatum causam, em geral, sintomas semelhantes como as podridões de frutos em pós-colheita (Peres et al., 2002). O morangueiro (Fragaria $\mathrm{x}$ ananassa Duch.), por exemplo, pode ser infectado por C. fragariae Brooks, C. acutatum e C. gloeosporioides (Gunnel \& Gubler, 1992). As três espécies causam antracnose, mas a podridão dos pedúnculo, inflorescências e frutos conhecida como "Flor Preta" é atribuída a C. acutatum. Outras culturas como a amêndoa (Prunus amygdalus L.) (Forster \& Adaskaveg, 1999), maçã (Malus domestica Borkh.) (Bernstein et al., 1995), abacate (Persea americana Mill.) (Jonhston \& Jones, 1997), pêssego (Prunus persica (L.) Batsch.) (Adaskaveg \& Hartin, 1997); citros (Brown et al., 1996; Goes \& Kimati, 1997) e algumas solanáceas (Tozze Jr. et al., 2006) são infectadas por C. acutatum e C. gloeosporioides. No Brasil, entre as fruteiras tropicais, C. acutatum foi associado somente à goiabeira (Psidium guajava L.) (Peres et al., 2002), embora tenha sido descrito inicialmente em $C$. papaya por Simmonds (1965), na Austrália.

Métodos moleculares são ferramentas úteis na diferenciação das espécies do gênero Colletotrichum (Lopez, 2001). A comparação de seqüências da região ITS 1 do rDNA entre C. gloeosporioides e outras espécies do gênero levaram ao desenvolvimento de oligonucleotídeos (primers) taxon-específicos para a diferenciação entre C. gloeosporioides e C. acutatum por PCR (reação da polimerase em cadeia) (Mills et al., 1992). Esses primers têm sido utilizados para a confirmação da identidade de isolados patogênicos a diversas hospedeiras (Adaskaveg \& Hartin, 1997; Freeman et al., 1998; Freeman et al., 2001; Peres et al., 2002; Afanador-Kafuri et. al., 2003).

A identificação das espécies de Colletotrichum patogênicas a uma determinada hospedeira, bem como a determinação de sua variabilidade, são fundamentais para o desenvolvimento de estratégias mais eficientes de controle, além de propiciar um melhor entendimento da epidemiologia da doença. No Brasil existem poucos estudos referentes à caracterização de Colletotrichum associado ao mamoeiro e estes, em geral, envolvem um número reduzido de isolados (Peres et al., 2002; Peres, 2002). O objetivo deste estudo foi caracterizar a variabilidade morfológica, cultural e patogênica de C. gloeosporioides isolados do mamoeiro e investigar a possível ocorrência de mais de uma espécie de Colletotrichum associada aos sintomas de antracnose e mancha-chocolate em frutos coletados nas duas principais regiões produtoras do Brasil, Bahia e Espírito Santo.

\section{MATERIAL E MÉTODOS}

\section{Origem, cultivo e preservação dos isolados}

Um total de 29 isolados monospóricos de Colletotrichum oriundos de frutos e pecíolos de mamão Sunrise Solo e Formosa foram utilizados neste estudo. Para fins comparativos, foram incluídos quatro isolados de outras hospedeiras: manga (Mangifera indica L.), morango e maçã, previamente identificados como C. gloeosporioides e $C$. acutatum (Tabela 1). Em todos os ensaios, os isolados foram cultivados em meio peptona-glucose-ágar (PGA) ou meio batata-dextrose-agar (BDA) a $25^{\circ} \mathrm{C}$, com fotoperíodo de 12 $\mathrm{h}$. As culturas foram mantidas por repicagens periódicas em meio BDA e em água estéril.

\section{Caracterização cultural e morfológica dos isolados}

Discos de micélio de $6 \mathrm{~mm}$ de diâmetro foram extraídos das margens de culturas de 5 dias crescidas em PGA e transferidos para novas placas contendo BDA ou PGA. Após 7 dias observou-se a coloração das colônias, o aspecto do micélio aéreo e a coloração do reverso das colônias. Para cada isolado foram utilizadas três repetições. Para observação da presença de setas e ocorrência da fase teleomórfica, as colônias foram examinadas por um período até 40 dias. O crescimento micelial foi estimado em BDA e PGA, através da leitura das médias entre os dois diâmetros ortogonais da colônia em intervalos de $24 \mathrm{~h}$ durante 5 dias. $\mathrm{O}$ delineamento estatístico foi inteiramente casualizado com três repetições por isolado e a taxa de crescimento micelial foi obtida pela análise de regressão linear (Zar, 1999) com o programa SAS (version 6.1, SAS Institute Inc., Cary, NC, EUA.). As médias dos valores de crescimento micelial somente no $5^{\circ}$ dia de cultivo foram comparadas através do teste de Tukey $(\mathrm{p} \leq 0,05)$, nos dois meios de cultura.

A sensibilidade dos isolados ao fungicida benomyl, foi avaliada em BDA contendo $1250 \mathrm{ppm}$ de benomyl de acordo com Sato (1996). Mediu-se o diâmetro da colônia a cada 24 h durante 5 dias. Para cada isolado foram utilizadas três repetições comparando-se o crescimento em BDA com benomyl com o crescimento no meio sem o fungicida. A taxa de crescimento micelial foi obtida conforme descrito anteriormente. 
Caracterização morfocultural e molecular de isolados de Colletotrichum gloeosporioides...

TABELA 1 - Designação, origem geográfica, hospedeira e ano de isolamento dos isolados de Colletotrichum spp. utilizados neste estudo

\begin{tabular}{|c|c|c|c|c|}
\hline Isolado $\mathrm{n}^{0}$ & Local de origem & $\begin{array}{l}\text { Órgão de Isolamento/ } \\
\text { Tipo de sintoma }\end{array}$ & $\begin{array}{c}\text { Hospedeira/ } \\
\text { cultivar }\end{array}$ & $\begin{array}{l}\text { Ano de } \\
\text { coleta }\end{array}$ \\
\hline 8 & Faz. Agronol, Luiz Eduardo Magalhães/BA & Fruto/Antracnose & Mamão / Formosa & 2000 \\
\hline 12 & Faz. Agronol, Luiz Eduardo Magalhães/BA & Fruto/Antracnose & Mamão/ Formosa & 2000 \\
\hline 21 & Faz. Canto do Rio, Luiz Eduardo Magalhães/BA & Fruto/Antracnose & Mamão / Sunrise Solo & 2000 \\
\hline 27 & Faz. Canto do Rio, Luiz Eduardo Magalhães/BA & Fruto/Antracnose & Mamão/ Formosa & 2000 \\
\hline 29 & Faz. Canto do Rio, Luiz Eduardo Magalhães/BA & Fruto/Antracnose & Mamão/ Formosa & 2000 \\
\hline 37 & Faz. Canto do Rio, Luiz Eduardo Magalhães/BA & Fruto/Antracnose & Mamão/ Sunrise Solo & 2000 \\
\hline 38 & Faz. Canto do Rio, Luiz Eduardo Magalhães/BA & Fruto/ Antracnose & Mamão/ Sunrise Solo & 2000 \\
\hline 40 & Faz. Canto do Rio, Luiz Eduardo Magalhães/BA & Fruto/Antracnose & Mamão/ Formosa & 2000 \\
\hline 45 & Faz. Canto do Rio, Luiz Eduardo Magalhães/BA & Fruto/ Antracnose & Mamão/ Sunrise Solo & 2000 \\
\hline 55 & Faz. Canto do Rio, Luiz E duardo Magalhães/BA & Fruto/Antracnose & Mamão/ Formosa & 2000 \\
\hline 59 & Faz. Canto do Rio, Luiz Eduardo Magalhães/BA & Fruto/ Antracnose & Mamão/ Formosa & 2000 \\
\hline 61 & Faz. Agronol, Luiz Eduardo Magalhães/BA & Fruto/Antracnose & Mamão/ Formosa & 2000 \\
\hline 62 & Faz. Caliman, Linhares/ES & Pecíolo & Mamão/ Sunrise Solo & 2001 \\
\hline 64 & Faz. Caliman, Linhares/ES & Pecíolo & Mamão/ Sunrise Solo & 2001 \\
\hline 65 & Faz. Lagoa Nova, Linhares/ES & Pecíolo & Mamão/ Sunrise Solo & 2001 \\
\hline 67 & Brasília/ DF & Fruto/ Antracnose & Mamão/ Formosa & 2001 \\
\hline 68 & Faz. Caliman, Linhares/ES & Pecíolo & Mamão/ Sunrise Solo & 2001 \\
\hline 69 & Faz. Caliman, Linhares/ES & Pecíolo & Mamão/ Sunrise Solo & 2001 \\
\hline 71 & Faz. Poletto, Luiz Eduardo Magalhães/BA & Pecíolo & Mamão/ Sunrise Solo & 2001 \\
\hline 72 & Estação Biológica, Brasília/DF & Fruto/ Antracnose & Mamão/ Sunrise Solo & 2001 \\
\hline 73 & Faz. Lagoa Nova, Linhares/ES & Fruto/ Antracnose & Mamão/ Sunrise Solo & 2001 \\
\hline 74 & Faz. Lagoa Nova, Linhares/ES & Pecíolo & Mamão/ Formosa & 2001 \\
\hline 75 & Faz. Grande Oeste, Luiz Eduardo Magalhães/BA & Pecíolo & Mamão/ Formosa & 2001 \\
\hline 76 & Faz. Grande Oeste, Luiz Eduardo Magalhães/BA & Pecíolo & Mamão/ Formosa & 2001 \\
\hline 77 & Faz. Grande Oeste, Luiz Eduardo Magalhães/BA & Pecíolo & Mamão/ Formosa & 2001 \\
\hline 78 & Faz. Agronol, Luiz Eduardo Magalhães/BA & Fruto/ Mancha chocolate & Mamão/ Formosa & 2001 \\
\hline 79 & Faz. Grande Oeste, Luiz Eduardo Magalhães/BA & Pecíolo & Mamão/ Formosa & 2001 \\
\hline 80 & Faz. Grande Oeste, Luiz Eduardo Magalhães/BA & Pecíolo & Mamão/ Formosa & 2001 \\
\hline 81 & Faz. Agronol, Luiz Eduardo Magalhães/BA & Fruto/ Antracnose & Mamão/ Formosa & 2001 \\
\hline 63 & Montes Claros/MG & Folha & Manga & 2001 \\
\hline 66 & - & Fruto & Maçã/ Gala ${ }^{3}$ & 2001 \\
\hline${ }^{1}$ UnB-1916 & Brazlândia/ DF & - & Morango & 2000 \\
\hline${ }^{2} \mathrm{UnB}-1611$ & Faz. Água Limpa, Brasília/DF & - & Manga & 1996 \\
\hline
\end{tabular}

${ }^{1}$ Coleção Micológica UnB; isolado identificado e depositado como Colletotrichum acutatum;

${ }^{2}$ Coleção Micológica UnB isolado identificado e depositado como Colletotrichum gloeosporioides;

${ }^{3}$ Maçã Gala comercializada em Brasília, DF.

Conídios e apressórios foram caracterizados em relação ao tamanho e forma, determinados para 50 conídios/ apressórios de cada isolado. Quanto ao formato, os conídios foram classificados em quatro grupos: 1) cilíndrico: com ambas as extremidades arredondadas; 2) elipsóide: com extremidades estreitas; 3) obcláveo: com uma das extremidades arredondadas e a outra estreita (forma de clava); 4) fusiforme: com ambas as extremidades agudas 
(Sutton, 1992). Para a caracterização dos apressórios, preparou-se uma suspensão de 1-2 x $10^{6}$ conídios $/ \mathrm{mL}$, a partir de culturas de 9 dias em meio PGA. A suspensão foi distribuída em meio ágar-água e 3 lamínulas foram colocadas sobre o meio. Após 2-4 dias, as lamínulas foram retiradas do meio e depositadas sobre lâminas, com ou sem adição do corante azul de algodão, para observação dos apressórios ao microscópio. Quanto à morfologia, os apressórios foram classificados em: 1) irregular e lobado: com as margens onduladas; 2) irregular e fracamente lobado: com as margens pouco onduladas; 3) circular e liso: com as margens sem ondulação (Sutton, 1992).

\section{Caracterização patogênica}

Frutos sadios de mamão cv. Sunrise Solo, provenientes do município de Luiz Eduardo MagalhãesBA e comercializados na CEASA-DF, foram submetidos ao método de desinfecção de acordo com Sanchez (1990). Os frutos foram feridos superficialmente com um agulha esterilizada. Com auxílio de um cotonete esterilizado embebido em uma suspensão contendo 1-2 x 106 conídios/ $\mathrm{mL}$ de cada um dos isolados (culturas de 7 dias em PGA), espalhou-se o inóculo sobre o ferimento. Os frutos foram colocados em bacias de plástico revestidas com papel toalha umedecido, cobertas com filme plástico e mantidas em incubadora (Percival Scentific, Inc, Boone IA, EUA) a $24{ }^{\circ} \mathrm{C}$, com fotoperíodo de $12 \mathrm{~h}$. As avaliações foram feitas aos 3, 5 e 9 dias após a inoculação, de acordo com a seguinte escala de notas: 0 - frutos sem sintomas; 1 - início de formação de pequenas lesões de cor castanha no local do ferimento; 2 lesões mais acentuadas, castanhas, superficiais e com bordas encharcadas; 3 - lesões com diâmetro de 2-3 cm, com bordas encharcadas e centro enegrecido; 4- lesão deprimida, escura, de diâmetro maior que $3 \mathrm{~cm}$, com intensa esporulação. $\mathrm{O}$ experimento foi conduzido em um delineamento inteiramente casualizado, com 4 repetições por isolado. Cada repetição foi constituída de um fruto inoculado em dois pontos. Como controle, frutos foram inoculados com água estéril. A análise estatística dos dados consistiu na transformação destes em valores de Área Abaixo da Curva de Progresso da Doença (Campbell \& Madden, 1990), considerando-se as leituras realizadas nas três épocas de avaliação. Com as notas e valores de AACPD, foi feita a análise de agrupamento por UPGMA (unweighted pair group method with arithmetic means) no programa GENSTAT 5 (Lawes Agricultural Trust, Rothamsted Experimental Station, Inglaterra).

\section{Caracterização molecular}

Para extração do DNA genômico dos isolados, massa micelial foi produzida em frascos contendo $200 \mathrm{~mL}$ de meio líquido PG inoculado com oito discos de micélio e mantidos sob agitação a $150 \mathrm{rpm}$ por 10 dias, a $25{ }^{\circ} \mathrm{C}$. Após esse período, o micélio foi filtrado a vácuo, lavado com água destilada esterilizada, liofilizado e mantido a -20 ${ }^{\circ} \mathrm{C}$ até o momento da extração. DNA foi extraído de acordo com Chen et al. (1993) com as seguintes modificações: a precipitação do DNA com isopropanol foi realizada por 12 $\mathrm{h}$ a $-20{ }^{\circ} \mathrm{C}$ e o precipitado foi recuperado por centrifugação a 7.200 x $g$ por $20 \mathrm{~min}$, lavado duas vezes com $200 \mu \mathrm{L}$ de etanol $70 \%$ e ressuspendido em $50 \mu \mathrm{L}$ de TE contendo $20 \mu \mathrm{g} / \mathrm{mL}$ de RNAse. A quantificação do DNA foi feita em gel de agarose a $1 \%$ corado com brometo de etídio $(1 \mu \mathrm{g} /$ $\mathrm{mL}$ ), através da comparação visual com o marcador DNA $\lambda$ HindIII (Pharmacia Biotech, San Francisco, CA, EUA) de concentração conhecida. Todas as amostras foram diluídas em água esterilizada para $10-20 \mathrm{ng} / \mu \mathrm{l}$ e armazenadas a $-20^{\circ} \mathrm{C}$.

Para a amplificação por PCR da região ITS (espaçador transcrito interno) do DNA ribossomal (rDNA), utilizou-se os primers ITS1 e ITS 4 (White et al., 1990), sintetizados pela Life Technologies, Inc., em reações de 25 $\mu \mathrm{L}$, contendo: tampão $1 \mathrm{X}(50 \mathrm{mM} \mathrm{KCl}, 10 \mathrm{mM}$ Tris $\mathrm{HCl})$; 1,5 $\mathrm{mM}$ de $\mathrm{MgCl}_{2} .1 \mu \mathrm{M}$ de cada primer; 0,2 $\mathrm{mM}$ de cada um dos dNTPs; 1,25 U de Taq DNA polimerase e 30-60 ng de DNA. A PCR foi realizada em termociclador RoboCycler 96 (Stratagene, La Jolla, CA, EUA) com um ciclo inicial de desnaturação a $95{ }^{\circ} \mathrm{C}$ por $2 \mathrm{~min}$, seguido de 35 ciclos de: $95{ }^{\circ} \mathrm{C}$ por $1 \mathrm{~min}, 55^{\circ} \mathrm{C}$ por $1 \min$ e $72{ }^{\circ} \mathrm{C}$ por $1 \min 30 \mathrm{~s}$, com extensão final a $72{ }^{\circ} \mathrm{C}$ por $10 \mathrm{~min}$. Os produtos de PCR foram digeridos separadamente com as endonucleases $R s a \mathrm{I}$ e $M s p \mathrm{I}$. A digestão foi realizada em $10 \mu \mathrm{L}$, sendo $5 \mu \mathrm{L}$ de DNA amplificado, $15 \mathrm{U}$ de cada enzima de restrição e $1 \mu \mathrm{L}$ de tampão específico para cada enzima, a $37^{\circ} \mathrm{C}$ durante 12 h. Em seguida, os fragmentos de restrição foram separados em gel de agarose a $2 \%$, em tampão TBE $0,5 \mathrm{X}$, a $90 \mathrm{~V}$, por cerca de $3 \mathrm{~h}$. Cada reação foi repetida duas vezes para cada isolado.

PCR com primers taxon-específicos foi realizada de acordo com Freeman et al. (2001). Os primers CgInt (5'GGCCTCCCGCCTCCGGGCGG3'), específico para $C$. gloeosporioides e CaInt2(5'GGGGAAGCCTCTCGCGG3'), específico para C. acutatum, foram usados em combinação com o primer ITS 4 para amplificação da região ITS. As reações foram preparadas em $25 \mu \mathrm{L}$, conforme descrito no item acima, e a PCR foi conduzida a uma temperatura de desnaturação de $95{ }^{\circ} \mathrm{C}$ por $2 \mathrm{~min}$, seguida de 35 ciclos de: $95{ }^{\circ} \mathrm{C}$ por $1 \mathrm{~min}, 60^{\circ} \mathrm{C}$ por $1 \mathrm{~min}$, e $72{ }^{\circ} \mathrm{C}$ por $1 \mathrm{~min}$ e $30 \mathrm{~s}$, e extensão final a $72{ }^{\circ} \mathrm{C}$ por $5 \mathrm{~min}$. Em todos os experimentos, controles negativos (reações livres de DNA) foram incluídos. Os produtos de PCR foram separados em gel de agarose a $1 \%$ em tampão TBE $0,5 \mathrm{X}$, a 90 V. Os géis foram corados com brometo de etídio $(1 \mu \mathrm{g} / \mathrm{mL})$ durante 15 min, descorados em água destilada por $40 \mathrm{~min}$, visualizados e fotografados através do sistema Eagle Eye (Stratagene).

\section{RESULTADOS E DISCUSSÃO}

\section{Caracterização cultural e morfológica dos isolados}

Os 33 isolados de Colletotrichum spp. apresentaramse bastante heterogêneos quanto à coloração (variando de branco a cinza-escuro) e aspecto das colônias tanto em em meio BDA quanto em meio PGA. Observações e descrições das culturas em meio BDA foram realizadas, o que permitiu 
agrupá-las em 7 tipos distintos (Tabela 2). No grupo A, foram reunidos 13 isolados de mamão e $\mathrm{UnB} 1916$ (C. acutatum), o que corresponde à maioria dos isolados analisados $(42 \%)$. Oito isolados (24\%) foram classificados no grupo B. Três isolados $(65,69$ e 79) apresentaram características do grupo C, e outros três $(12,27$ e 64) do grupo D. Os isolados 67, 63 e UnB 1611 (C. gloeosporioides) foram inseridos no grupo E; os isolados 8 e 62 apresentaram características diferentes dos demais e foram classificados nos grupos $\mathrm{F}$ e G, respectivamente (Tabela 3). Dentre os sete isolados do Espírito Santo, detectou-se seis grupos culturais. Entre os 20 isolados da Bahia, também foram identificados seis tipos culturais. Peres (2002) analisou oito isolados de $C$. gloeosporioides de mamão, sendo cinco da Bahia e três do Espírito Santo, e também observou tipos distintos de colônias, além de mudança na cor e tipo de micélio de acordo com o meio de cultura utilizado. Adaskaveg \& Hartin (1997) caracterizaram oito isolados de C. gloeosporioides de mamão do Havaí, EUA. Estes apresentavam micélio aéreo de coloração cinza com massa de esporos alaranjada e coloração cinza-clara a esverdeada no reverso das colônias. A descrição desses isolados enquadra-se no grupo cultural $\mathrm{D}$, observado neste estudo. No entanto, este não foi o tipo predominante entre os isolados brasileiros aqui estudados.

Em BDA, os isolados que mais cresceram foram 29 , $68,72,61$ e 59 , com taxas de crescimento superiores a 1,1 $\mathrm{cm} / \mathrm{dia}$, e os que menos se desenvolveram foram 62 e 67 (taxas inferiores a $0,9 \mathrm{~cm} / \mathrm{dia}$ ) (Tabela 3). Os isolados 63 e UnB 1611, ambos C. gloeosporioides, cresceram mais rápido em $\mathrm{BDA}$ do que os isolados de C. acutatum $(66 \mathrm{e}$ UnB1916). C. gloeosporioides é descrito como tendo crescimento mais rápido, quando comparado à $C$. acutatum (Gunnel \& Gubler, 1992; Smith \& Black, 1990), o que foi confirmado em nosso estudo. Dezesseis isolados de mamão $(55 \%)$ apresentaram taxas superiores a $1 \mathrm{~cm} / \mathrm{dia}$, acima do observado para o isolado UnB 1916 (C. acutatum).
Comparando-se os isolados quanto ao diâmetro da colônia, ao $5^{\circ}$ dia, observou-se diferença estatística significativa quanto ao meio de cultura (dados não mostrados). Em PGA, os isolados apresentaram média de crescimento $(4,95 \mathrm{~cm})$ inferior que em $\operatorname{BDA}(5,30 \mathrm{~cm})$.

$\mathrm{O}$ teste de sensibilidade ao benomyl em BDA foi avaliado de acordo com metodologia de Sato (1996) que considerou tolerantes os isolados cuja relação (em \%) entre o crescimento em meio contendo benomyl na concentração de 1250 ppm comparado ao meio sem fungicida era superior a $20 \%$, e sensíveis quando o valor era inferior a $20 \%$. No presente estudo, 22 isolados de mamão $(75,9 \%$ do total) e os dois isolados de mangueira (63 e UnB 1611) mostraramse sensíveis ao fungicida, com crescimento no meio com fungicida em relação ao controle inferior a $20 \%$ (Tabela 3 ). No entanto, os isolados de C. acutatum, UnB 1916 e 66, e sete isolados de mamão $(24,1 \%)$ mostraram-se tolerantes com crescimento em BDA contendo benomyl superior a $20 \%$ do controle (Tabela 3). Em geral, isolados de $C$. gloeosporioides são considerados altamente sensíveis ao benomyl, enquanto $C$. acutatum é relativamente insensível (Freeman et al., 1998). Isto foi aqui confirmado para os isolados de manga, morango e maçã, em acordo com Sato (1996) que mostrou que para C. acutatum, a relação entre o crescimento na presença de benomyl e o no meio sem fungicida era superior a $20 \%$ (tolerante), enquanto que para C. gloeosporioides o valor era inferior. Em mamoeiro, contudo, observou-se variabilidade entre os isolados. Isolados tolerantes foram identificados tanto em localidades da Bahia quanto do Espírito Santo e todos foram identificados morfologicamente como C. gloeosporioides (Tabela 4). Adaskaveg \& Hartin (1997) observaram sensibilidade ao benomyl em oito isolados de C. gloeosporioides de mamão provenientes do Havaí. Resultado diferente foi obtido por Peres et al. (2002) que observaram tolerância ao benomyl em um isolado de mamão do Nordeste brasileiro, embora a

TABELA 2 - Variabilidade dos aspectos culturais dos isolados de Colletotrichum spp. de mamão e outras hospedeiras, observados em meio BDA, aos 7 dias

\begin{tabular}{|c|c|c|c|c|}
\hline Grupo & Cor da colônia & $\begin{array}{l}\text { Borda da } \\
\text { colônia }\end{array}$ & Reverso da colônia & Micélio aéreo \\
\hline$\overline{\mathbf{A}}$ & Salmão & Branca & Salmão & $\begin{array}{l}\text { Presente, } \\
\text { moderadamente abundante }\end{array}$ \\
\hline B & Cinza escuro & Branca & $\begin{array}{l}\text { Cinza escuro ao centro, com bordas } \\
\text { brancas }\end{array}$ & Presente, cotonoso e escuro \\
\hline $\mathbf{C}$ & $\begin{array}{l}\text { Cinza escuro no centro } \\
\text { e branca ao redor }\end{array}$ & Branca & $\begin{array}{l}\text { Cinza escuro no centro e bordas } \\
\text { brancas esverdeadas }\end{array}$ & Presente, mas reduzido \\
\hline D & $\begin{array}{l}\text { Cinza claro no centro, } \\
\text { com bordas brancas }\end{array}$ & Branca & $\begin{array}{l}\text { Cinza escuro no centro e branco } \\
\text { esverdeado ao redor }\end{array}$ & $\begin{array}{l}\text { Presente, moderadamente } \\
\text { abundante. Cor branca, não } \\
\text { cotonoso }\end{array}$ \\
\hline $\mathbf{E}$ & Branca & Branca & Branca & Reduzido e branco \\
\hline $\mathbf{F}$ & $\begin{array}{l}\text { Cinza claro no centro, } \\
\text { abundante esporulação de cor } \\
\text { laranja no centro }\end{array}$ & Branca & $\begin{array}{l}\text { Borda branca, } \\
\text { centro alaranjado com pontuações } \\
\text { escuras }\end{array}$ & $\begin{array}{l}\text { Presente, } \\
\text { moderadamente abundante }\end{array}$ \\
\hline $\mathbf{G}$ & Negra & Branca & Centro negro e borda branca & Ausente \\
\hline
\end{tabular}

Fitopatol. Bras. 32(1), jan - fev 2007 
TABELA 3- Características culturais dos isolados de Colletotrichum spp. de mamoeiro e outras hospedeiras

\begin{tabular}{|c|c|c|c|c|c|c|}
\hline \multirow[t]{2}{*}{ Isolado } & \multicolumn{3}{|c|}{$\begin{array}{l}\text { Taxa de crescimento } \\
\text { de colônia }(\mathrm{cm} / \mathrm{dia})^{\mathrm{a}}\end{array}$} & \multirow[t]{2}{*}{$\operatorname{Setas}^{\mathrm{c}}$} & \multirow[t]{2}{*}{ Teleomorfo $^{d}$} & \multirow[t]{2}{*}{$\begin{array}{c}\text { Grupo de coloração } \\
\text { de colônia }^{\text {e }}\end{array}$} \\
\hline & $\mathbf{B D A}+\mathbf{B}^{\mathbf{b}}$ & BDA & $\%(\mathbf{B D A}+\mathbf{B}) / \mathbf{B D A}$ & & & \\
\hline 8 & 0,000 & 1,060 & 0,0 & - & - & F \\
\hline 12 & 0,093 & 0,988 & 9,4 & - & - & $\mathrm{D}$ \\
\hline 21 & 0,242 & 1,095 & 22,1 & - & - & A \\
\hline 27 & 0,191 & 1,034 & 18,5 & - & - & $\mathrm{D}$ \\
\hline 29 & 0,000 & 1,100 & 0,0 & - & - & $\mathrm{B}$ \\
\hline 37 & 0,267 & 1,092 & 24,5 & - & - & B \\
\hline 38 & 0,000 & 1,056 & 0,0 & - & - & A \\
\hline 40 & 0,000 & 1,007 & 0,0 & - & - & A \\
\hline 45 & 0,184 & 0,980 & 18,8 & + & - & B \\
\hline 55 & 0,569 & 0,916 & 62,1 & - & - & A \\
\hline 59 & 0,288 & 1,123 & 25,6 & + & - & A \\
\hline 61 & 0,070 & 1,246 & 5,6 & - & - & B \\
\hline 62 & 0,000 & 0,584 & 0,0 & - & - & G \\
\hline 64 & 0,322 & 1,041 & 30,9 & - & - & D \\
\hline 65 & 0,166 & 0,934 & 17,8 & - & - & $\mathrm{C}$ \\
\hline 67 & 0,000 & 0,883 & 0,0 & + & - & $\mathrm{E}$ \\
\hline 68 & 0,624 & 1,316 & 47,4 & + & + & B \\
\hline 69 & 0,095 & 1,034 & 9,2 & - & - & $\mathrm{C}$ \\
\hline 71 & 0,000 & 0,982 & 0,0 & - & - & A \\
\hline 72 & 0,060 & 1,276 & 4,7 & + & - & B \\
\hline 73 & 0,306 & 1,003 & 30,5 & - & - & A \\
\hline 74 & 0,155 & 0,995 & 15,6 & - & - & A \\
\hline 75 & 0,000 & 0,979 & 0,0 & - & - & A \\
\hline 76 & 0,000 & 1,083 & 0,0 & - & - & A \\
\hline 77 & 0,000 & 0,904 & 0,0 & - & - & A \\
\hline 78 & 0,157 & 0,983 & 15,9 & - & - & A \\
\hline 79 & 0,000 & 0,940 & 0,0 & - & - & $\mathrm{C}$ \\
\hline 80 & 0,093 & 0,978 & 9,5 & - & - & B \\
\hline 81 & 0,183 & 1,087 & 16,8 & - & - & A \\
\hline 63 & 0,070 & 1,037 & 6,8 & - & - & $\mathrm{E}$ \\
\hline 1611 & 0,000 & 1,037 & 0,0 & - & - & $\mathrm{E}$ \\
\hline 66 & 0,255 & 0,937 & 27,2 & - & - & B \\
\hline 1916 & 0,207 & 0,993 & 20,8 & - & - & A \\
\hline
\end{tabular}

acrescimento da colônia durante 5 dias consecutivos a $24{ }^{\circ} \mathrm{C}$ com 3 repetições por isolado; taxas obtidas através de regressão linear ( inclinação da reta tangente);

b1250 ppm de benomyl em meio BDA;

${ }^{c}+$ ) presença; (-) ausência de setas, observada em meio PGA;

${ }^{\mathrm{d}}(+)$ presença da fase teleomórfica Glomerella cingulata em meio PGA; (-) fase teleomórfica não observada;

'de acordo com os grupos definidos na Tabela 2.

concentração do fungicida usada tenha sido menor.

A presença de setas não foi observada em nenhum isolado em BDA. Em PGA, observou-se a presença de setas em cinco isolados (Tabela 3). As setas apresentaramse morfologicamente semelhantes em todos os isolados, com coloração cinza escura a negra, asseptadas, e com dimensões médias 93 x 3,6 $\mu \mathrm{m}$. A produção de setas é uma característica variável entre isolados de Colletotrichum spp. associados a diferentes hospedeiras. Por exemplo, Carvalho (1997) não observou setas em meio PGA em nenhum dos 38 isolados de C. gloeosporioides e C. acutatum associados à podridão amarga de frutos de macieira. Entre isolados de Colletotrichum patogênicos ao morangueiro, observou-se que somente $C$. fragariae produziu setas em cultura (BDA) e na hospedeira, não observadas em C. gloeosporioides ou C. acutatum (Smith \& Black, 1990), no entanto, isolados das três espécies produziram setas morfologicamente distintas em meio SLA (strawberry leaf agar) (Gunnel \& Gubler, 1992). A ausência de setas nas colônias de Colletotrichum pode estar associada à composição do meio de cultura além de fatores ambientais, tais como níveis de aeração, umidade do ar, temperatura e fotoperíodo. Em C. coccodes 
Caracterização morfocultural e molecular de isolados de Colletotrichum gloeosporioides...

TABELA 4 - Características morfológicas dos isolados de Colletotrichum spp. utilizados neste estudo

\begin{tabular}{|c|c|c|c|c|c|c|c|}
\hline \multirow[t]{2}{*}{ Isolado } & \multicolumn{3}{|c|}{ Conídio } & \multicolumn{3}{|c|}{ Apressório } & \multirow[t]{2}{*}{ Espécie } \\
\hline & Formato & $\begin{array}{l}\text { Tamanho } \\
(\mu \mathrm{m})^{\mathrm{a}}\end{array}$ & $\begin{array}{l}\text { Relação } \\
\text { comp. / } \\
\text { largura }\end{array}$ & Formato & $\begin{array}{c}\text { Tamanho } \\
(\mu \mathrm{m})^{\mathrm{b}}\end{array}$ & $\begin{array}{l}\text { Relação } \\
\text { Comp. / } \\
\text { largura }\end{array}$ & \\
\hline 8 & cilind./ obcl. & $13,75 \times 4,73$ & 2,92 & circular/ liso & $10,76 \times 6,84$ & 1,61 & C. gloeosporioides \\
\hline 12 & cilind./ obcl. & $13,86 \times 4,94$ & 2,85 & lobado & $10,5 \times 7,51$ & 1,45 & C. gloeosporioides \\
\hline 21 & cilind./ obcl. & $13,39 \times 4,37$ & 3,13 & lobado & $8,52 \times 6,98$ & 1,26 & C. gloeosporioides \\
\hline 27 & cilind./ obcl. & $15,00 \times 4,89$ & 3,07 & frac. lobado & $9,67 \times 6,96$ & 1,45 & C. gloeosporioides \\
\hline 29 & cilind./ obcl. & $14,46 \times 4,45$ & 3,35 & frac. lobado & $8,09 \times 6,34$ & 1,32 & C. gloeosporioides \\
\hline 37 & cilind./ obcl. & $13,83 \times 4,37$ & 3,24 & frac. lobado & $9,78 \times 6,60$ & 1,51 & C. gloeosporioides \\
\hline 38 & cilind./ obcl. & $13,10 \times 4,84$ & 2,75 & circular, liso & $9,59 \times 6,63$ & 1,51 & C. gloeosporioides \\
\hline 40 & cilind./ obcl. & $12,43 \times 4,60$ & 2,76 & frac. lobado & $9,65 \times 7,54$ & 1,33 & C. gloeosporioides \\
\hline 45 & cilind./ obcl. & $13,05 \times 4,69$ & 2,81 & frac. lobado & $9,46 \times 5,95$ & 1,62 & C. gloeosporioides \\
\hline 55 & cilind./ obcl. & $13,94 \times 4,90$ & 2,86 & lobado & $8,27 \times 7,10$ & 1,22 & C. gloeosporioides \\
\hline 59 & cilind./ obcl. & $12,92 \times 4,58$ & 2,90 & frac. lobado & $10,09 \times 7,49$ & 1,42 & C. gloeosporioides \\
\hline 61 & cilíndrico & $12,95 \times 4,00$ & 3,54 & frac. lobado & $8,57 \times 6,48$ & 1,37 & C. gloeosporioides \\
\hline 62 & cilind./ obcl. & $11,93 \times 5,08$ & 2,36 & lobado & $9,10 \times 6,78$ & 1,36 & C. gloeosporioides \\
\hline 64 & cilind./ obcl. & $12,87 \times 4,95$ & 2,61 & liso/frac.lob. & $10,66 \times 6,76$ & 1,63 & C. gloeosporioides \\
\hline 65 & cilind./ obcl. & $13,65 \times 4,84$ & 2,83 & lobado & $8,86 \times 7,13$ & 1,31 & C. gloeosporioides \\
\hline 67 & elipsóide & $13,62 \times 3,98$ & 3,45 & circular, liso & $8,66 \times 8,09$ & 1,08 & C. gloeosporioides \\
\hline 68 & cilind./ obcl. & $16,12 \times 5,33$ & 3,04 & frac. lobado & $14,38 \times 8,68$ & 1,68 & C. gloeosporioides \\
\hline 69 & cilind./ obcl. & $14,77 \times 4,53$ & 3,29 & lobado & $9,23 \times 7,07$ & 1,36 & C. gloeosporioides \\
\hline 71 & cilind./ obcl. & $13,18 \times 5,03$ & 2,63 & lobado & $8,14 \times 6,84$ & 1,26 & C. gloeosporioides \\
\hline 72 & cilind./ obcl. & $12,66 \times 4,15$ & 3,12 & lobado & $9,44 \times 7,09$ & 1,38 & C. gloeosporioides \\
\hline 73 & cilind./ obcl. & $14,61 \times 5,10$ & 2,87 & frac. lobado & $8,98 \times 5,78$ & 1,64 & C. gloeosporioides \\
\hline 74 & cilíndrico & $12,87 \times 4,88$ & 2,66 & lobado & $9,98 \times 6,60$ & 1,55 & C. gloeosporioides \\
\hline 75 & cilind./ obcl. & $12,32 \times 4,92$ & 2,52 & lobado & $9,44 \times 6,29$ & 1,56 & C. gloeosporioides \\
\hline 76 & cilind./ obcl. & $13,34 \times 4,54$ & 2,95 & frac. lobado & $9,46 \times 6,73$ & 1,45 & C. gloeosporioides \\
\hline 77 & cilind./ obcl. & $12,72 \times 4,74$ & 2,69 & lobado & $11,44 \times 6,53$ & 1,82 & C. gloeosporioides \\
\hline 78 & cilind./ obcl. & $12,77 \times 4,70$ & 2,72 & lobado & $10,56 \times 6,47$ & 1,73 & C. gloeosporioides \\
\hline 79 & cilind./ obcl. & $13,78 \times 4,88$ & 2,93 & lobado & $9,46 \times 7,05$ & 1,42 & C. gloeosporioides \\
\hline 80 & cilind./ obcl. & $13,52 \times 5,15$ & 2,63 & lobado & $11,33 \times 7,92$ & 1,48 & C. gloeosporioides \\
\hline 81 & cilind./ obcl. & $13,10 \times 4,56$ & 2,88 & lobado & $10,35 \times 7,67$ & 1,40 & C. gloeosporioides \\
\hline 63 & cilind./ obcl. & $13,00 \times 4,74$ & 2,78 & lobado & $9,19 \times 6,79$ & 1,44 & C. gloeosporioides \\
\hline 1611 & cilindrico & $12,40 \times 4,90$ & 2,56 & lobado & $9,80 \times 7,30$ & 1,55 & C. gloeosporioides \\
\hline 66 & cilind./ obcl./fusif & $11,44 \times 2,96$ & 3,98 & $\mathrm{Nd}$ & $\mathrm{Nd}$ & $\mathrm{Nd}$ & C. acutatum \\
\hline 1916 & fusiforme & $11,70 \times 2,99$ & 4,02 & circular/liso & $8,50 \times 9,80$ & 1,30 & C. acutatum \\
\hline
\end{tabular}

${ }^{\text {a }}$ média das dimensões de 50 conídios, produzidos em PGA, após 15 dias de cultivo ( $25^{\circ} \mathrm{C}, 12 \mathrm{~h}$ fotoperíodo);

${ }^{\mathrm{b}}$ média das dimensões de 50 apressórios;

$\mathrm{Nd}=$ não determinado: isolado não produziu apressórios;

formato dos conídios: cilind.= cilíndrico; obcl. =obcláveo; fusif.= fusiforme;

formato dos apressórios: frac. lobado= fracamente lobado.

foi demonstrado que a aeração e o fotoperíodo tiveram efeitos marcantes na produção de conídios e setas a partir de esclerócios (Sanogo \& Pennypacker, 1997).

A formação de peritécios foi observada somente no isolado 68 em PGA, após 20 dias de cultivo (Tabela 3). O teleomorfo foi identificado como Glomerella cingulata (Stoneman) Spauld. \& Schrenk, por apresentar a maioria dos peritécios com formato globoso, com largura média de 161 
$\mu \mathrm{m}$. Os 50 ascósporos medidos eram oblongos, curvos, com dimensões médias de 17,7 x 6,3 $\mu \mathrm{m}$; ascos unitunicados, clavados a cilíndricos contendo oito ascósporos. Glomerella acutata Guerber \& Correll (teleomorfo de C. acutatum) possui peritécio ampuliforme ou obpiriforme, os ascos podem conter oito ou menos ascósporos e estes são retos e menores $(15,7$ x 5,8 $\mu \mathrm{m})$ que os de $G$. cingulata (Guerber \& Correll, 2001). A baixa freqüência de formação de peritécios em meio de cultura observada neste estudo, também foi relatada entre isolados de outras hospedeiras tais como, pupunheira (Mafacioli et al., 2006) e abacate (Freeman et al., 1998).

Dentre os 29 isolados do mamoeiro, foram observados três formatos de conídios: cilíndrico, obcláveo e elipsóide (Tabela 4). Destes, 26 apresentaram formato cilíndrico e obcláveo; dois apresentaram formato apenas cilíndrico e um isolado apresentou conídios predominantemente elipsóides. A variação no comprimento dos conídios foi de 10,4 a $18,2 \mu \mathrm{m}$, e na largura entre 3,9 a $6,5 \mu \mathrm{m}$. A diferença mais marcante observada foi que somente os dois isolados de $C$. acutatum, apresentaram relação comprimento/ largura superior a 3,9, o que não foi observado em nenhum dos demais isolados identificados como C. gloeosporioides (Tabela 4).

Quanto à morfologia dos apressórios, o formato lobado (irregular) foi o predominante, observado em 15 isolados (Tabela 4). No isolado 64 foi observada, com a mesma freqüência, a presença de apressórios ovalados, de margens lisas, e fracamente lobados. O isolado 66 (maçã) não produziu apressórios; o isolado UnB 1916 (morango) mostrou apressórios circulares e lisos, e os isolados de manga apresentaram formato lobado, com dimensões similares (Tabela 4). A variabilidade no formato de apressórios de Colletotrichum é bem documentada, sendo um mesmo isolado capaz de apresentar tipos morfológicos distintos, o que dificulta a delimitação precisa entre espécies (Mafacioli et al., 2006; Tozze Jr. et al., 2006).

De acordo com todas as características observadas, os 29 isolados de mamão foram identificados como $C$. gloeosporioides, segundo Sutton (1992) (Tabelas 3 e 4). As características que melhor distinguiram os isolados de mamão foram o formato dos conídios (cilíndrico e/ou obcláveo) e sua relação comprimento/largura inferior a 3,9, e a produção de apressórios lobados ou fracamente lobados. Nenhum isolado apresentou conídios fusiformes, afilados nas duas extremidades, característica típica de C. acutatum. A diferenciação entre espécies com base nas dimensões de conídios e apressórios foi dificultada pela sobreposição dos valores descritos por Sutton (1992), pois a maioria dos isolados de mamão apresentou dimensões dentro da faixa de variação descrita para as duas espécies, $C$. gloeosporioides e C. acutatum. O telemorfo é também um critério usado para a definição de espécie. No entanto, no presente estudo, dos 29 isolados de mamão, apenas um (68) apresentou a fase teleomórfica ( $G$. cingulata). As características morfoculturais confirmaram a identificação prévia dos isolados UnB 1916 e 66 como C. acutatum, e de UnB 1611 e 63, como C. gloeosporioides (Tabela 4). O isolado 67 apresentou características intermediárias, com apressórios de margens lisas e conídios elipsóides, e foi identificado como C. gloeosporioides por possuir tamanho dos conídios e apressórios que se enquadram na descrição desta espécie, além da coloração de colônia branca. Da mesma forma, os isolados 8 e 38 apesar de terem os apressórios circulares e lisos, apresentaram conídios predominantemente cilíndricos, característicos de C. gloeosporioides.

\section{Caracterização patogênica}

Todos os 33 isolados foram patogênicos aos frutos de mamão cv. Sunrise Solo, produzindo sintomas característicos de antracnose aos 9 dias após a inoculação. Inicialmente surgiram pequenas manchas de coloração marrom, evoluindo para manchas pretas e deprimidas, formando um halo de tecido aquoso, com coloração diferente da parte central. Observou-se variação no diâmetro e intensidade das lesões formadas, indicando níveis diferentes de agressividade entre os isolados. Os resultados confirmam o observado por Peres et al. (2002) que, ao inocularem frutos de mamão com isolados de C. gloeosporioides de diferentes hospedeiras e com $C$. acutatum de morango, verificaram que todos eram patogênicos aos frutos de mamão. O potencial de espécies de Colletotrichum para a infecção cruzada tem sido demonstrado em vários estudos (Freeman \& Shabi, 1996; Freeman et al., 1998; Lima-Filho et al., 2003), fator que pode favorecer a disseminação da antracnose em várias frutíferas se não forem adotadas medidas de controle eficientes. C. acutatum é descrito como um fungo cosmopolita, patógeno de várias fruteiras subtropicais e temperadas, e potencialmente capaz de infectar frutos de mamão como demonstrado por Peres et al. (2002) e confirmado no presente estudo. No Brasil, contudo, sua ocorrência natural em fruteiras tropicais, aparentemente, limita-se à goiabeira.

Os isolados foram classificados em dois grupos quanto à agressividade sendo o primeiro composto por 10 isolados de mamão e o UnB 1916, e o segundo pelos demais (Tabela 5). O isolado 62 está entre os de menor agressividade e também o que obteve menor velocidade de crescimento micelial tanto em BDA quanto em PGA.

Os isolados obtidos de frutos de mamão com sintomas de antracnose (Tabela 1) produziram nos frutos sintomas idênticos aos produzidos pelo isolado 78, obtido de fruto com mancha-chocolate. Também não foram observadas diferenças morfoculturais entre esses isolados. Segundo Alvarez \& Nishijima (1987), um mesmo isolado pode causar tanto a lesão de antracnose quanto a mancha-chocolate. Nenhuma diferença quanto ao tipo ou evolução de sintomas foi observada entre os 17 isolados de frutos, comparados aos 12 de pecíolos. Segundo Dickman (1994), isolados do pecíolo, quando inoculados em frutos, não causam lesão de antracnose ou mancha-chocolate, no entanto, no presente trabalho, todos os isolados de pecíolo foram patogênicos aos frutos e produziram lesões típicas. 
TABELA 5 - Agressividade dos isolados de Colletotrichum spp. inoculados em frutos de mamão cv. Sunrise Solo comparada pelos valores de AACPD obtidos pelos índices de doença ao $5^{\circ}, 7^{\circ}$ e $9^{\circ}$ dia após a inoculação

\begin{tabular}{|c|c|c|}
\hline Isolado & $\mathbf{A A C P D}^{1}$ & Grupo de agressividade ${ }^{2}$ \\
\hline 8 & 14,87 & 1 \\
\hline 78 & 14,75 & 1 \\
\hline 67 & 12,37 & 1 \\
\hline 72 & 12,00 & 1 \\
\hline 80 & 12,00 & 1 \\
\hline 45 & 11,75 & 1 \\
\hline 29 & 11,50 & 1 \\
\hline 37 & 11,25 & 1 \\
\hline 73 & 10,25 & 1 \\
\hline 65 & 9,50 & 1 \\
\hline 1916 & 9,50 & 1 \\
\hline 66 & 9,12 & 2 \\
\hline 1611 & 8,87 & 2 \\
\hline 64 & 8,50 & 2 \\
\hline 79 & 8,00 & 2 \\
\hline 61 & 7,62 & 2 \\
\hline 27 & 7,62 & 2 \\
\hline 59 & 7,56 & 2 \\
\hline 74 & 7,50 & 2 \\
\hline 12 & 7,25 & 2 \\
\hline 69 & 6,62 & 2 \\
\hline 21 & 6,62 & 2 \\
\hline 81 & 6,50 & 2 \\
\hline 68 & 6,37 & 2 \\
\hline 38 & 6,25 & 2 \\
\hline 63 & 6,25 & 2 \\
\hline 75 & 6,00 & 2 \\
\hline 77 & 6,00 & 2 \\
\hline 71 & 5,87 & 2 \\
\hline 76 & 5,50 & 2 \\
\hline 55 & 5,00 & 2 \\
\hline 62 & 4,50 & 2 \\
\hline 40 & 4,25 & 2 \\
\hline \multicolumn{3}{|c|}{$\begin{array}{l}{ }^{1} \text { Valores transformados em Área Abaixo da Curva } \\
\text { de Progresso da Doença (AACPD), de acordo com } \\
\text { Campbell e Madden (1990). } \\
{ }^{2} \text { Grupos definidos pela análise de agrupamento via } \\
\text { UPGMA (unweighted pair group method using } \\
\text { arithmetic means). }\end{array}$} \\
\hline
\end{tabular}

\section{Caracterização molecular}

A amplificação usando-se os primers CgInt/ITS 4 foi positiva apenas para quatro isolados de mamão $(61,67,68 \mathrm{e}$ 72) e para os isolados 63 e UnB 1611, gerando fragmentos de $\sim 500 \mathrm{pb}$. Quando se utilizou CaInt2/ITS 4, detectou-se amplificação com apenas dois isolados de mamão (75 e 76) e com os isolados de C. acutatum. Com a maioria dos isolados de mamão (23) não foi obtida amplificação com nenhum dos pares de primers, mesmo após serem testadas variações nas condições da PCR (temperaturas de anelamento de 55 e $60{ }^{\circ} \mathrm{C}$ ) e diferentes concentrações de DNA. O uso dos primers taxon-específicos confirmou a identidade dos isolados 63 e UnB 1611 como C. gloeosporioides, dos isolados 66 e UnB 1916 como C. acutatum, mas de apenas quatro isolados de mamão identificados morfologicamente como C. gloeosporioides. Com o primer CaInt2, a reação de amplificação foi positiva com os isolados 75 e 76, mas nenhuma característica morfocultural destes isolados coincide com a descrição de C. acutatum.

Esses mesmos primers específicos foram usados para confirmar a identidade de isolados de mamão do Havaí como C. gloeosporioides (Adaskaveg \& Hartin, 1997; Foster \& Adaskaveg, 1999), mas os resultados aqui obtidos sugerem uma baixa especificidade dos primers em relação aos isolados de mamão coletados na BA e ES. Suas seqüências foram obtidas a partir do sequenciamento da região ITS de isolados de morango, o que torna possível que haja pouca homologia nesta região com os isolados de mamão. A variabilidade genética na população brasileira de Colletotrichum associados ao mamão, também explicaria porque somente o DNA de alguns isolados foi amplificado pelo primer CgInt, específico para C. gloeosporioides. Assim, os primers descritos por Freeman et al. (2001), por sua baixa especificidade, tiveram utilidade apenas como um critério complementar para a caracterização de isolados do mamoeiro. A incongruência observada aqui entre os critérios morfológicos e a identificação molecular também foi observada por Afanador-Kafuri et al. (2003) que encontraram isolados de maracujá, manga e "tamarillo" [Cyphomandra betacea (Cav.) Sendth], identificados como C. gloeosporioides de acordo com a morfologia, que não puderam ser identificados com nenhum dos dois pares de primers. Mesmo após o sequenciamento completo da região ITS, alguns isolados não puderam ser classificados em nenhuma das duas espécies, o que poderia sugerir a existência de outra(s) espécie(s) associada(s) à antracnose nessas culturas.

A região ITS do rDNA, amplificada com os primers universais ITS1 / ITS4, gerou um fragmento de mesmo tamanho $(\sim 600 \mathrm{pb})$ para todos os 33 isolados. Para a análise de RFLP foram testadas duas endonucleases. Com MspI, quatro perfis distintos foram obtidos para os 33 isolados, mas sem relação com a identidade ou origem dos isolados (dados não mostrados). RsaI clivou os fragmentos de rDNA de 28 dos 29 isolados de mamão em um único sítio de restrição gerando dois fragmentos de tamanhos aproximados de 380 e $180 \mathrm{pb}$ (Figura 1) Os isolados de manga 63 e UnB 1611 apresentaram o mesmo perfil de restrição que os isolados de mamão. Já os produtos de PCR dos isolados 66 e UnB 1916 não foram clivados pela enzima RsaI e o mesmo foi observado com o isolado 68. Freeman et al. (2001) mostraram a ocorrência de um único sítio de restrição de $R s a \mathrm{I}$ na região ITS de C. gloeosporioides, mas os isolados de C. acutatum foram divididos em dois sub-grupos: aqueles com um sítio, mas produzindo perfil de restrição diferente do de C. gloeosporioides e outro, sem o sítio de restrição. Neste estudo, a análise de ITS-RFLP com RsaI gerou um perfil 


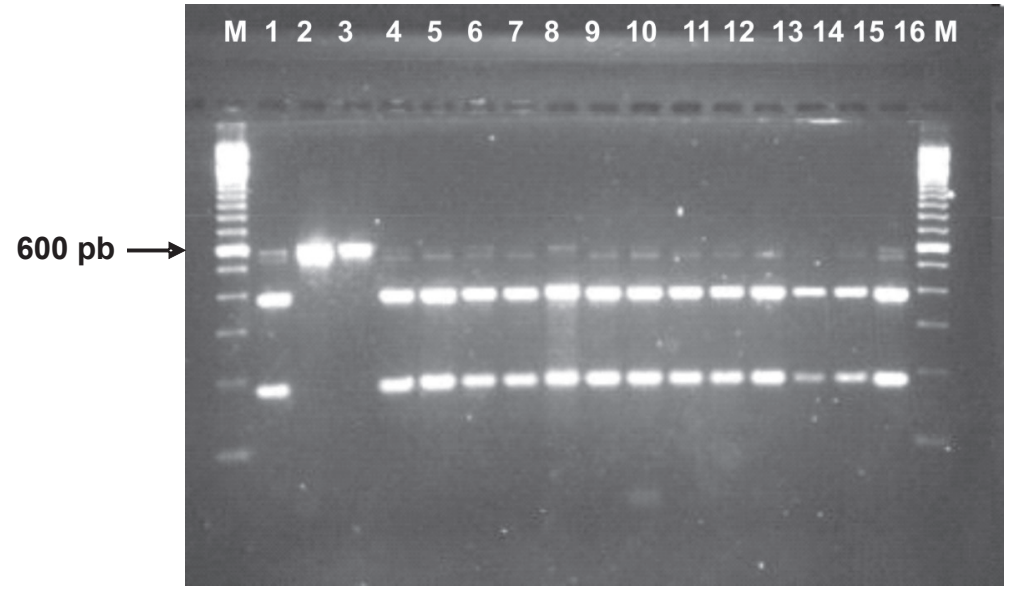

FIG. 1 - Análise da restrição com a endonuclease $R s a \mathrm{I}$ da região ITS do rDNA amplificada com os primers ITS1 e ITS4. Colunas 1 a 16 correspondem, respectivamente, aos isolados: 63 (Colletotrichum gloeosporioides), UnB1916 (C. acutatum), 66 (C. acutatum), UnB1611, 8, 12, 21, 27, 29, 37, 38, 40, 45, 55, 59 e 61, todos C. gloeosporioides. $\mathrm{M}=$ marcador 100 bp-DNA ladder. Gel de agarose 2\%. único para a maioria $(96,5 \%)$ dos isolados estudados. Aúnica exceção foi o isolado 68 que gerou perfil semelhante a $C$. acutatum (sem o sítio de restrição). Contudo, este isolado apresenta todas as características morfoculturais de $C$. gloeosporioides e sua identidade foi ainda confirmada pelo primer CgInt, específico para C. gloeosporioides.

Características fenotípicas e genotípicas avaliadas neste estudo confirmaram ser C. gloeosporioides o agente causal da antracnose e da mancha-chocolate do mamoeiro. Nenhum dos isolados coletados mostrou um conjunto de características condizentes com a descrição de C. acutatum. Contudo, a existência de isolados intermediários e a falta de convergência entre os caracteres morfológicos e a identificação por PCR, sugere que a população de Colletotrichum associada ao mamoeiro no Brasil é heterogênea e deve ser melhor caracterizada genotipicamente através de métodos moleculares adicionais como AP-PCR e o sequenciamento das regiões ITS, mtDNA, genes da $\beta$-tubulina ou de compatibilidade sexual (MAT1-2), cuja eficiência na caracterização e identificação de isolados já foi comprovada em estudos com outras hospedeiras (Freeman, et al. 1998; Sreenivasaprasad \& Talhinhas, 2005; Du et al., 2005). Os 29 isolados associados ao mamoeiro apresentaram grande variabilidade nas características morfoculturais e também em agressividade quando inoculados nos frutos. Dentre os caracteres avaliados neste estudo, a morfologia e relação comprimento/ largura dos conídios e a análise de ITS-RFLP com RsaI mostraram-se os mais adequados para identificação e caracterização dos isolados do mamoeiro.

\section{AGRADECIMENTOS}

Os autores agradecem a CAPES pela bolsa concedida a E.M. Andrade, ao Dr. Milton Paz Lima pela colaboração na análise dos resultados e a Juliana Alves Batista de Aquino pela ajuda na realização dos experimentos.

\section{REFERÊNCIAS BIBLIOGRÁFICAS}

ADASKAVEG, J.E. \& HARTIN, R.J. Characterization of Colletotrichum acutatum isolates causing anthracnose of almond and peach in California. Phytopathology 87:979-987. 1997.

AFANADOR-KAFURI, L., MINZ, D., MAYMON, M. \& FREEMAN, S. Characterization of Colletotrichum isolates from tamarillo, passiflora, and mango in Colombia and identification of a unique species from the genus. Phytopathology 93:579-587. 2003.

ALVAREZ, A. \& NISHIJIMA, W.T. Post-harvest diseases of papaya. Plant Disease 71:681-686. 1987.

BERNSTEIN, B., ZEHR, E.I., DEAN, R.A. \& SHABI, E. Characteristics of Colletotrichum from peach, apple, pecan, and other hosts. Plant Disease 79:478-482. 1995.

BROWN, A.E., SREENIVASAPRASAD, S. \& TIMMER, W.L. Molecular characterization of slow-orange key lime anthracnose strains of Colletotrichum from citrus as C.acutatum. Phytopathology 86:523-527. 1996

CAMPBELL, C.L. \& MADDEN, L.M. Introduction to plant disease epidemiology. New York. John Wiley Sons. 1990.

CARVALHO, F.M.S. Caracterização cultural, morfológica e genética de espécies de Colletotrichum associadas a doenças em macieira. Dissertação de Mestrado. Londrina. Universidade Estadual de Londrina. 1997.

CHEN, X., LINE, R.F \& LEUNG, H. Relationship between virulence variation and DNA polymorphism in Puccinia striiformis. Phytopathology 83:1489-1497. 1993.

DICKMAN, M.B. Anthracnose In: Ploetz, R.C., Zentmyer, G.A.; Nishijima, W.T., Rohrbach, K.G. \& Ohr H.D. (Eds.) Compendium of tropical fruit diseases. Saint Paul MN. APS Press. 1994. pp. 5859.

DU, M., SCHARDL, C.L., NUCKLES, E.M. \& VAILLANCOURT, L.J. Using mating-type gene sequences for improved phylogenetic resolution of Colletotrichum species complexes. Mycologia 97:641-658. 2005.

FORSTER, H. \& ADASKAVEG, J.E. Identification of subpopulations of Colletotrichum acutatum and epidemiology of almond anthracnose in California. Phytopathology 89:1056-1065. 1999. 
FREEMAN, S., KATAN, T. \& SHABI, E. Characterization of Colletotrichum species responsible for anthracnose diseases of various fruits. Plant Disease 82:596-605. 1998.

FREEMAN, D.S., MINZ, D., MAYMON, M. \& ZVEIBIL, A. Genetic diversity within Colletotrichum acutatum sensu Simmonds. Phytopathology 91:586-592. 2001.

FREEMAN, S. \& SHABI, E. Cross infection of subtropical and temperate fruits by Colletotrichum species from various hosts. Physiological and Molecular Plant Pathology 49:395-404.1996.

GAYET, J.P., BLEINROTH, E.W., MATALLO, M., GARCIA, E.E.C., GARCIA, A. E., ARDITO, E.F.G. \& BORDIN, M.R. Mamão para exportação: Procedimentos de colheita e pós-colheita. Ministério da Agricultura, do Abastecimento e da Reforma Agrária, Secretaria de Desenvolvimento Rural, Programa de Apoio à Produção e Exportação de Frutas, Hortaliças e Plantas Ornamentais. EMBRAPA-SPI. 1995.

GOES, A. \& KIMATI, H. Caracterização morfológica de isolados de Colletotrichum acutatum e C. gloeosporioides associados à queda prematura dos frutos cítricos. Summa Phytopatologica 23:5-13. 1997.

GUERBER, J.C. \& CORRELL, J.C. Characterization of Glomerella acutata, the teleomorph of Colletotrichum acutatum. Mycologia 93:216-229. 2001

GUNNEL, P. \& GUBLER, W.D. Taxonomy and morphology of Colletotrichum species pathogenic to strawberry. Mycologia 84:157-165. 1992.

JOHNSTON, P.R. \& JONES, D. Relationships among Colletotrichum isolates from fruit-rots assessed using rDNA sequences. Mycologia 89:420-430.1997.

LIMA FILHO, R.M., OLIVEIRA, S.M.A.\& MENEZES, M. Caracterização enzimática e patogenicidade cruzada de Colletotrichum spp. associados a doenças de pós-colheita. Fitopatologia Brasileira 28:620-625. 2003.

LOPEZ, A.M.Q. Taxonomia, patogênese e controle de espécies do gênero Colletotrichum. Revisão Anual de Patologia de Plantas 9:291-337. 2001.

MAFACIOLI, R., TESSMANN, D.J., SANTOS, A.F. \& VIDA J.B. Caracterização morfo-fisiológica e patogenicidade de Colletotrichum gloeosporioides da pupunheira. Summa Phytopathologica 32:113-117. 2006.

MILLS, P.R., HODSON, A. \& BROWN, A.E. Molecular differentiation of Colletotrichum gloeosporioides isolates infecting tropical fruit. In: Bailey, J.A. \& Jeger, M.J. (Eds.) Colletotrichum: Biology, pathology and control. Wallingford. CAB International. 1992. pp. 269-288.

OLIVEIRA, A.A.R., BARBOSA, C.J., SANTOS FILHO, H.P. \& MEISSNER FILHO, P.E. Mamão Produção:Aspectos Técnicos. Embrapa Mandioca Fruticultura. Cruz das Almas, BA. - Brasília: Embrapa
Comunicação para Transferência de Tecnologia. Brasília. 2000.

PERES, A.P. Podridão peduncular de mamão: variabilidade dos agentes etiológicos e aspectos fisiopatológicos na pós-colheita. Dissertação de Mestrado. Universidade Federal de Lavras. 2002.

PERES, N.A.R., KURAMAE, E.E., DIAS, M.S.C. \& SOUZA, N.L. Identification and characterization of Colletotrichum spp. affecting fruit after harvest in Brazil. Journal of Phytopathology 150:128-134. 2002.

PERES, N.A., TIMMER, L.W., ADASKAVEG, J.E. \& CORRELL, J.C. Lifestyles of Colletotrichum acutatum. Plant Disease 89:784796. 2005.

SANCHEZ, M. Podridão preta do fruto do mamoeiro. Dissertação de Mestrado. Brasília. Universidade de Brasília. 1990.

SANOGO, S. \& PENNYPACKER, S.P. Factors affecting sporogenic and myceliogenic germination of sclerotia of Colletotrichum coccodes. Plant Disease 81:333-336. 1997.

SATO, T. Problems of taxonomy and identification of Colletotrichum species. Plant Protection 50: 273-280. 1996.

SIMMONDS, J.H. A study of the species Colletotrichum causing ripe fruit rots in Queensland. Queensland Journal of Agricultural and Animal Sciences 22:437-459. 1965.

SMITH, B.J. \& BLACK, L.L. Morphological, cultural and pathogenic variation among Colletotrichum sp. isolated from strawberry. Plant Disease 74:69-76. 1990.

SREENIVASAPRASAD, S. \& TALHINHAS, P. Genotypic and phenotypic diversity in Colletotrichum acutatum, a cosmopolitan pathogen causing anthracnose on a wide range of hosts. Molecular Plant Pathology 6:361-378. 2005.

SUTTON, B.C. The genus Glomerella and its anamorph Colletotrichum. In: Bailey, J.A. \& Jeger, M.J. (Eds.) Colletotrichum - Biology, Pathology, and Control. Wallingford. CAB International. 1992. pp. 1-26.

TOZZE JR., H.J., MELLO, M.B.A. \& MASSOLA JR., N.S. Morphological and physiological characterization of Colletotrichum sp. isolates from solanaceous crops. Summa Phytopathologica 32:71-79. 2006.

UENO, B., FERREIRA, M.A.S.V. \& UESUGI, C.H. Levantamento das principais doenças do mamoeiro (Carica papaya L.) na região de Barreiras, BA. Fitopatologia Brasileira 26:386. 2001. (Resumo)

WHITE, T.J., BRUNS, T. \& TAYLOR, J. Amplification and direct sequencing of fungal ribosomal RNA genes for phylogenetics. In: Innis, M.A., Gelfand, D.H., Shinsky, J.J. \& White, T.J. (Eds.) PCR Protocols: A guide to methods and applications. New York. Academic Press. 1990. pp. 315-322.

ZAR, J.H. Biostatistical analysis. 4th ed. New Jersey. Prentice Hall. 1999. 